\title{
Modern Dzikir and Spiritual Crisis
}

\author{
Iim Suryahim 1, Uus Putria², Muslim³ \\ ${ }^{1}$ Universitas Islam Al-Ihya (Unisa) Kuningan \\ ${ }^{2}$ STAI Siliwangi,Bandung \\ ${ }^{3}$ STAI Al Hidayah Bogor \\ * Corresponding author E-mail: iimsuryahim84@gmail.com
}

\begin{abstract}
Modern humans are more likely to be known as materialists and far from spiritual values. This study aims to determine the relationship of the Qur'an's spirituality in overcoming the spiritual crisis of modern human life. This research uses qualitative methods or literature review. The results of this study indicate that in some studies, modern humans who are closer to the Qur'an are mainly those who practice Dzikir to live more mature spiritually. Keywords: Al-Qur'an, Dzikir, Spiritual Crisis.
\end{abstract}

Keyword: Al-Qur'an, Dzikir, Spiritual Crisis

\section{INTRODUCTION}

According to experts observing social problems, that the characteristics of modern society will experience existential frustration that is characterized by an excessive desire to rule (the will to power), looking for the pleasure of life (the will to pleasure), always wanting to hoard wealth (the will to money), do not know the time at work so do not have time to socialize (the will to work), and have a fairly high libido tendency (the will to sex). As a result of this disease, making life arid, empty and empty without purpose so that negative behaviors arise such as crime, violence, delinquency, suicide, murder, sexual relations out of wedlock, persecution, broken home, rape, drug addiction, divorce and sexual behavior distorted and various other moral crises as a result (Rohmawati \& Ismail, 2017)

Many experts who lament this age as the century of human fall, because the soul of the people who blossomed as God's creatures is no longer found because the reality of their lives is only looking at the material and forgetting religion, although not rejecting God in oral form, but denying it in the form of behavior (Goddess, 2017). Every human being, even every family, seems to be meeting with the problem of a spiritual crisis. The impact of the institution that feels the most problems is the family, so to anticipate it requires intelligence and endurance of the family, namely with a religious approach by believing and obeying all the commands of God.

According to the research of Tamrin et al that dzikir is very good at lowering blood sugar (Tamrin, Widyaningsih, \& Windiyastuti, 2020). Likewise with research Ayu Mesta Rahayu which proves that there is an effect of Dzikir on someone's resignation behavior (Rahayu, 2019). Nisa and Anton also explained the function of the mosque which influenced the decline in spiritual crisis (Khairuni \& Widyanto, 2018). this study presents data to see the function of Dzikir in one's spiritual life, especially in humans - modern humans, and for know the impact so we can study Dzikir more deeply.

Spiritual calm is very necessary for humans - people in the modern era like today, some problems often make a person experience depression and result in the emergence of choices to commit suicide,

* Copyright (c) 2020 Iim Suryahim et.all

This work is licensed under a Creative Commons Attribution-ShareAlike 4.0 International License.

Received: May 05, 2020; Revised: July 23, 2020; Accepted: July 24, 2020 
Dzikir considered to help our spiritual power to avoid negative thoughts that make our hearts become not calm.

\section{RESEARCH METHOD}

This study uses a qualitative method. Bodgan and Taylor in Moleong, define qualitative methodology as a research procedure that produces descriptive data in the form of written or oral words from people and observable behavior. book to study literature in studying all opinions and deepening understanding of the Koran (Moleong, 2012)

From these definitions, it can be concluded that qualitative research is research that intends to understand phenomena about what is experienced by research subjects such as behavior, perception, motivation, action, and others. Holistically, and using descriptions in the form of words and language, in a special natural context, and by utilizing various scientific methods (Moleong, 2012).

The data analysis method used is the qualitative descriptive Miles and Huberman. A method in qualitative data analysis is carried out interactively and takes place continuously until it is complete so that the data is saturated. A descriptive method is a method used in examining status, a group of people, an object, condition, and system of thought. Qualitative method is a systematic method of scientific research on parts and phenomena and their relationship.

\section{RESULTS AND DISCUSSION}

Life is now in the modern era, an era where life gets ease and comfort with various technological advancements. Technology helps someone in work, vacation, and even rest. Working in one's office is helped by computer facilities and internet connections, farmers are helped by tractor machines in plowing land.

According to the perspective of language 'spirituality' comes from the word 'spirit' which means 'soul' (Achmad, Layyinah, \& Rahman, 2019). And the term "spiritual" can be defined as a human experience in general from an understanding of meaning, purpose, and morality (BUDIYAWANTO, 2016).

In a psychological dictionary, the word spirit means an immaterial substance or being, usually divine, which is given the nature of many human characteristics, strength, energy, energy, morals, or motivation (Rois, 2019).

Spirituality in a broad sense is related to spirit. Something spiritual has eternal truth related to human life. One aspect of being spiritual is to have a direction and purpose in life that continuously enhances one's wisdom and willpower to achieve a closer relationship with God. In other words, Spirituality can answer what someone is.

Spirituality is an innate human need to connect with something greater than the human being. The term "something bigger than a human being" is something outside of

\section{Human being and attracts a feeling for that person.}

Spirituality is directed towards the subjective experience of what is existentially relevant to humans. Spirituality not only pays attention to whether life is valuable but also focuses on why life is valuable. Being spiritual means having more ties to things that are spiritual or psychological than things that are physical or material.

Spirituality is often associated with religion. But religion and spirituality have differences. Religion is often characterized as an institution, individual beliefs, and practices. While spirituality is often 
associated with connectedness or inner feelings with God. Spirituality is the belief that there is a nonphysical strength that is greater than self-power, an awareness that connects humans directly with God or whatever is called human existence (Komarudin \& Hidayat, 2020)

Spirituality is the basis for self-esteem, values, morals, and ownership. Spirituality is more a form of psychological experience that leaves a deep impression and meaning. While in children, the nature of spirituality is reflected in the unlimited creativity of broad imagination, and the approach to open and happy life.

In his book Duane Schultz, Maslow defines spirituality as a stage of self-actualization, in which a person is abundant with creativity, intuition, joy, joy, peace, tolerance, humility, and also has a clear purpose in life.

According to Maslow, spiritual experience is the highest peak that can be reached by humans and is an affirmation of its existence as a spiritual being. The highest human experience is the highest human need. Maslow even stated that spiritual experience had crossed the hierarchy of human needs. Maslow also argues that individual motivation does not lie in a series of movers, but rather focuses on hierarchy, certain higher needs are activated to expand lower and satisfying needs.

To find out more about the existence of spirituality that has worked effectively or that spirituality has moved in a positive direction in a person, then to find out we need to pay attention to some of its characteristics. Among them:

1. Having these clear and strong principles and principles of life, a person becomes truly independent and will not be enslaved by anyone. He moves under the guidance and also the strength of the principle on which he is based. By sticking to the principle of universal truth, one can face life with spiritual intelligence.

2. Choose the ability to deal with and utilize suffering and have the ability to deal with and surpass pain. Suffering is a ladder to a more perfect level of spiritual intelligence. Then there is no need to regret every event that happens to live. Face all suffering with a smile and determination because they are part of the process towards personal maturation in general, both intellectual, emotional, and spiritual maturity.

3. Able to interpret all the work and activities more in a framework and also a frame that is more class and meaningful. Whatever human role is carried out by someone, everything must be carried out for the task of universal humanity, for happiness, calm, and mutual comfort.

4. Have high self-awareness. Consciousness is the most important part of spirituality because among the functions of God Spot in the human brain is asking fundamental questions that question the existence of oneself. From this self-knowledge, one will get to know the purpose and mission of his life. Even from this introduction, one can know God.

It is undeniable that the progress of science and technology is increasingly felt by all people in all parts of the world. So that the world feels smaller, more globalized, and change continues to occur everywhere in every corner of life. This condition more or less contributes to life, so we need a handle that is eternal so as not to be dragged by the negative currents of globalization and modernization that may arise that is by holding on tightly to religion and running it continuously in life. Broadly speaking, the picture of people's lives is currently experiencing a variety of shifts because it continues to race and work hard to meet their needs so that religion is less attention because it is always associated with the materialistic world. Likewise with social life between people, almost only done when there are business interests or bring benefits in the form of material benefits. At least from this problem, it appears that 
modern society is experiencing a fall from its position of spiritual beings into material beings. So to restore human identity as God's most noble creatures, humans must return to the path of God by obedience to religion and by carrying out their duties properly. Only in this way can humans find peace and comfort so that they do not experience existential frustration.

Modern society is very devaluing of science and technology, while religious understanding based on revelation is abandoned and lives in a secular state. They tend to pursue material needs and hedonistic lifestyles rather than think of a religion that is considered to have no role.

Such a society has lost its vision of divinity, blunted its vision of the reality of life and life. The progress that has occurred has penetrated in various aspects of life, both social, economic, cultural, and political. This condition requires individuals to adapt to changes that occur quickly and surely. But in reality, not all individuals can do it, so what happens is society or people who save a lot of problems due to inequality

According to experts observing social problems, that the characteristics of modern society will experience existential frustration that is characterized by an excessive desire to rule (the will to power), looking for the pleasure of life (the will to pleasure), always wanting to hoard wealth (the will to money), do not know the time at work so do not have time to socialize (the will to work), and have a fairly high libido tendency (the will to sex). As a result of this disease, making life arid, empty and empty without purpose so that negative behaviors arise such as crime, violence, delinquency, suicide, murder, sexual relations out of wedlock, persecution, broken home, rape, drug addiction, divorce and sexual behavior distorted and various other moral crises as a result.

Many experts who lament this age as the century of the fall of man, because the soul of the people who blossomed as God's creatures is no longer found because the reality of their lives is only looking at matter and forgetting religion, although they do not reject God in oral form, but deny it in the form of behavior. Every human being, even every family, seems to be meeting with the problem of a spiritual crisis. The impact of the institution that feels the most problems is the family, so to anticipate it requires intelligence and endurance of the family, namely with a religious approach by believing and obeying all the commands of God.

With faith and obedience to God is an act of Dzikir, because the meaning of Dzikir is quite broad and includes including the implementation of activities based on faith. By dzikir, someone will get peace of mind because indeed Allah directly mentions that Dzikir brings peace. With calmness or serenity will bring out the sharpness of thought and analysis, which are the seeds that foster creativity. As revealed in a Persian poem that says: "Dzikir until your Dzikir pops up fikr, and gives birth to one hundred thousand pure thoughts (andishah)" (Nurcholis, 2012).

A spiritual crisis marked by unrest, so that the writer is interested in revealing interpretations of verses that correlate dealing with unrest, one of which is a picture of a believer whose heart is at peace with the remembrance of Allah; after death. (Surat Ar-Ra'du [13]: 28-29). On this basis, the author limits his study to Surah Ar-Radu verses 28-29.

To express tranquility, the tranquility of the soul as an element of spirituality, in this case, the author describes several commentators in interpreting the Ar-Ra'du verse 28 verse that there is a correlation between Dzikir and peace of heart. Opinions of the commentators (interpreting scholars) as follows:

\section{Opinions of Abu Sana 'Syihabuddin al-Sayyid Mahmud Afandi al-Alusi}




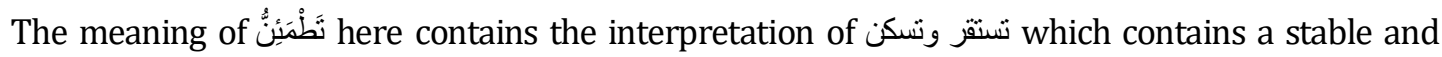

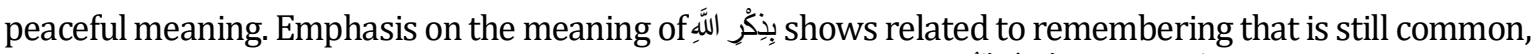

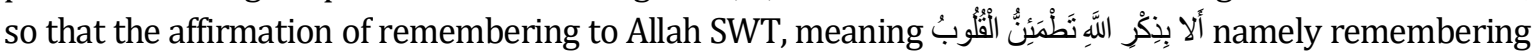
Allah SWT simply does not remember anything other than Allah SWT that is remembering from the things of the inclination to the nature of the world (Al-Alusi, n.d.).

\section{The opinion of Abdullah ibn Umar ibn Muhammad ibn Ali al-Baidawi}

Abdullah ibn Umar bin Muhammad ibn Alial-Baidawi expressed his views in his interpretation. The

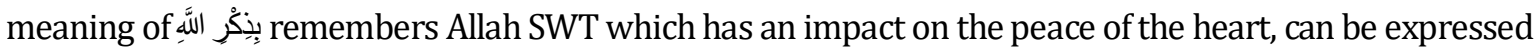
in three ways:

1. By remembering the love of Allah SWT after his heart was overcome by anxiety and fear of Him.

2. By remembering the evidence of His power which shows the totality of His essence.

3. By living up to his words contained in the Qur'an (Dardum, 2017).

4. Opinions of Muhammad ibn Abi Bakr ibn Ayub ibn Sa'd Shamsuddin ibn Qoyim Al-Jauziyah in his interpretation.

Lafadz تَنَفَيَن gives the term thuma'ninah which implies peace in the heart of something, the absence of anxiety and anxiety. It can be seen the impact of the famous saying "honesty brings peace, and lies bring unrest" ie honesty can appease listening to hearts, and there can be found peace of honesty. While lies have an impact on anxiety. This is as the hadith of the Prophet Muhammad SAW: kindness is something that appeals to the heart. Ie, peace of the heart, and loss of anxiety (Al-Jauziyah, n.d.). Ibn Qoyim interpreted that lafadz نكر الله had two views:

1. Lafadz نكر الله which means that he remembers the servant of his Lord. Then from remembering it has an impact on the peace of the heart. When the heart is upset, anxious which is a reflection of a spiritual crisis in the soul, then the cure for it all is to remember God.

2. Lafadz نكر اللهin question is the Qur'an, Allah has revealed the Qur'an which by reading the Qur'an can reassure hearts, hearts accompanied by faith and belief because the heart will not be at peace without faith and confidence.

\section{CONCLUSION}

Portraits of modern human life that are filled with daily life problems such as anxiety, anxiety, and life pressure can create a spiritual crisis. The condition is thick in this modern era so that patterns of handling are simpler namely Dzikir which can reassure everyone's heart.

\section{REFERENCES}

Achmad, A., Layyinah, R., \& Rahman, F. (2019). Generasi Insan Maju Berbasis Dalam Perspektif Tafsir Penyucian Jiwa Al-Mizan Thabataba'i. Hanifiya: Jurnal Studi Agama-Agama, 2(2), 113-128.

Al-Alusi, A. S. S. Al-S. M. A. (N.D.). Ruhul Ma'ani Fi Tafsiril Qur'an. Kairo: Darul Qutub Al-Mishriyah. Al-Jauziyah, M. Ibn A. B. Ibn A. Ibn S. S. Ibn Q. (N.D.). Tafsirul Qur'ana. Beirut: Dar Wa Maktabah AlHilal.

Budiyawanto, M. (2016). Manajemen Spiritual Pendidikan Anak Usia Dini. Biormatika: Jurnal Ilmiah Fakultas Keguruan Dan Ilmu Pendidikan, 2(01). 
Dardum, A. (2017). Teologi Asy'ari Dalam Kitab Tafsir (Analisa Metode Ta’wil Tafșīlī Dalam Memahami Ayat Istiwā'). Kalimah: Jurnal Studi Agama Dan Pemikiran Islam, 15(2), 149167.

Khairuni, N., \& Widyanto, A. (2018). Mengatasi Krisis Spiritual Remaja Di Banda Aceh Melalui Revitalisasi Dan Optimalisasi Fungsi Masjid Sebagai Sarana Pendidikan Islam Resolving Teenage Spiritual Crisis In Banda Aceh By Revitalizing And Optimizing The Functions of Masjid As An Islamic Educa. 1(1), 74-84.

Komarudin, P., \& Hidayat, M. R. (2020). Integrasi Literasi Ekonomi Syariah Dalam Mata Kuliah Pendidikan Agama Islam. Al Iqtishadiyah Jurnal Ekonomi Syariah Dan Hukum Ekonomi Syariah, 6(1), 1-18.

Moleong, L. J. (2012). Metodologi Penelitian Kualitatif. Bandung: Remaja Rosdakarya.

Nurcholis, A. (2012). Peran Tasawuf Dalam Merekonstruksi Krisis Spiritualitas Manusia Modern. Sosio Religi.

Rahayu, A. M. (2019). Pengaruh Zikir Tarekat Naqsyabandiyah Terhadap Perilaku Tawakal: Studi Deskriptif Di Pondok Pesantren Al-Quran Al-Falah 1 Cicalengka, Bandung. Rahayu, Ayu Mesta. "Pengaruh Zikir Tarekat Naqsyabandiyah Terhadap Perilaku Tawakal: Studi Deskriptif Di Pondok Pesantren Al-Quran Al-Falah 1 Cicalengka, Bandung." Uin Sunan Gunung Djati Bandung, 2019.: Uin Sunan Gunung Djati Bandung.

Rohmawati, A., \& Ismail, H. (2017). Ziarah Makam Walisongo Dalam Peningkatan Spiritualitas Manusia Modern. Sumbula: Jurnal Studi Keagamaan, Sosial Dan Budaya, 2(2), 612-627.

Rois, N. (2019). Konsep Motivasi, Perilaku, Dan Pengalaman Puncak Spiritual Manusia Dalam Psikologi Islam. Jurnal Progress: Wahana Kreativitas Dan Intelektualitas, 7(2).

Tamrin, T., Widyaningsih, T. S., \& Windiyastuti, W. (2020). Pengaruh Terapi Dzikir Terhadap Kadar Gula Darah Sewaktu Pada Lansia Diabetesi Di Wilayah Kerja Puskesmas Lebdosari Semarang. Jurnal Manajemen Asuhan Keperawatan, 4(1), 61-69. 